This pdf is a digital offprint of your contribution in J. De Volder (ed.), The Geopolitics of Pope Francis, ISBN 978-90429-4065-9.

The copyright on this publication belongs to Peeters Publishers.

As author you are licensed to make printed copies of the pdf or to send the unaltered pdf file to up to 50 relations. You may not publish this pdf on the World Wide Web including websites such as academia.edu and open-access repositories - until three years after publication. Please ensure that anyone receiving an offprint from you observes these rules as well.

If you wish to publish your article immediately on openaccess sites, please contact the publisher with regard to the payment of the article processing fee.

For queries about offprints, copyright and republication of your article, please contact the publisher via peeters@peeters-leuven.be 


\section{The Geopolitics of Pope Francis}

Edited by

Jan De Volder 


\section{Contents}

Acknowledgements. .................... VII

Jan De Volder

Francis's Ideosyncratic Approach to Vatican Geopolitics: An Introduction. .................. I

Sandra Arenas

Latin America in Francis's Geopolitical Thought . . . . . . . . . 25

Massimo Faggioli

The Geopolitics of Pope Francis and the USA . . . . . . . . . 47

Jan De Volder

Pope Francis's Views on the Rebirth of Europe........... 6I

Stefano Picciaredda

Pope Francis and Africa..................... 87

Agostino Giovagnoli

China and the Geopolitics of Pope Francis . . . . . . . . . . IO5

Terrence Merrigan

Between Doctrine and Discernment: Pope Francis on Interreligious

Dialogue ....................... I27

Marco Impagliazzo

Pope Francis and Islam . . . . . . . . . . . . I5I

Brandon Gallaher

The Pure Signifier of Power: Remembering, Repeating and Working through the Significance of the Papacy and Pope Francis for Eastern Orthodoxy. . . . . . . . . . . . . . . . . . . . 169

Johan Verstraeten

It Is Better to Build Bridges Than to Build Walls: Pope Francis on Peace and War.......................... I99 
Jan Wouters and Giuliana Rotola

Pope Francis's Interactions with the United Nations and Other

International Organizations....................... 209

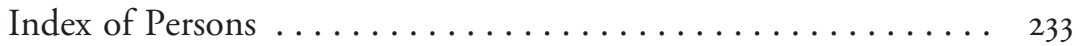

Index of Toponyms ...................... 239

List of Contributors........................ 243 


\title{
It Is Better to Build Bridges Than to Build Walls Pope Francis on Peace and War
}

\author{
Johan Verstraeten
}

Pope Francis's approach to peace and war is not based on abstract ethical reasoning, nor on a top-down application of rigid principles. Being averse to "mere generalities that challenge no one" (EG I82), he exhorts the people of God to "enter[ing] fully into the fabric of society, sharing the life of all" (EG 269). ${ }^{\mathrm{I}}$ His thinking is practical and starts from the presupposition that faith is transformative: "an authentic faith - which is never comfortable or completely personal - always implies a deep desire to change the world...." (EG I83). Peacebuilding is one of the concrete expressions of this transformative approach, and like any other of its expressions, it requires discernment. Francis has clearly articulated its meaning in his address to the Community of La Civiltà Cattolica:

This is the time of discernment in the Church and in the World. Discernment is always realized in the presence of the Lord, looking at the signs, listening to things that happen, the feelings of the people who know the humble way of the daily stubbornness, and especially the poor. But we need to penetrate ambiguity, we need to enter in there, as the Lord Jesus did assuming our flesh. ${ }^{2}$

From Francis's perspective, discerning with an open mind what ought to be done in order to let God's future emerge in concrete circumstances is much more important than proclaiming general truths and inflexible principles.

${ }^{1}$ In what follows I refer to the apostolic exhortation Evangelii Gaudium: The Joy of the Gospel (Vatican City: Libreria Editrice Vaticana, 2013) as EG and to Laudato Si. Encyclical Letter on Care for our Common Home (Vatican City: Libreria Editrice Vaticana, 20I5) as LS, each time followed by the paragraph number.

2 Pope Francis, "Discourse to the Community of La Civiltà Cattolica," La Civiltà Cattolica (February 9, 20I7), available at https://www.laciviltacattolica.it/articulo/discourse-of-the-holy-father-francis-to-the-community-of-la-civilta-cattolica. Another interesting address about discernment is To Have Courage and Prophetic Audacity? Dialogue of Pope Francis with the Jesuits Gathered in the 36th General Congregation (October 24, 2016), https://jesuits.org/Assets/Publications/File/GC36-Dialogue_of_Pope_Francis_ english.pdf. 
Pope Francis's transformational approach presupposes, moreover, a "real and sincere closeness" with people, especially poor people and migrants. This entails, according to Cardinal Kasper, a real "paradigm shift in method."' With regards to peacebuilding it means that it does not start from a neutral or outsider perspective, but from a genuine concern for people, letting oneself be touched by the victims of conflicts and the encounter with those whose action can have an impact on conflict transformation.

The aim of Francis's peace praxeology is, moreover, the fearless realization of the magis, the greater good in the perspective of God. As Father Antonio Spadaro said during the conference, Francis does not want to re-write history, but to move it forward. He is convinced that it is precisely in the real world with all its ambiguities, that something new and better can always emerge.

\section{I. "The Spirit of God Has Filled the Universe with Possibilities" (LS 80): Reality, Time and Conflict}

Francis's firm conviction that peace is possible is grounded in his dynamic and mystic interpretation of reality. In his thinking reality is not mere facticity or something static, nor a matter of realpolitik. It is a complex process of change, in which God moves the world forward towards new possibilities. Francis's articulation of this is crystal clear in Evangelii Gaudium, more precisely, in the paragraphs on the principle that "time has priority over space." This principle obliges everyone who in involved in action for peace to abandon the fixed "spaces of power and self-assertion" in which people, groups and states are imprisoned (EG 223). It obliges individuals and groups to leave their comfort zones, and to tear down the mental walls that narrow their understanding of events (EG 222). Such mental walls include sticking to fixed images of the "enemy," being paralyzed by fear, the refusal of cultural differences, distrusting migrants, etc. Francis believes that "we are always more effective when we generate processes rather than holding on positions of power" (LS 178). The consequence is that peace cannot be a sort of static tranquillitas ordinis, nor an anxious protection of the status quo. Peace is dynamic and requires a courageous engagement in a process of

3 Walter Cardinal Kasper, "Open House: How Pope Francis Sees the Church," Commonweal I42, no. 7 (2015): 5 . 
change, in which one makes "links in a constantly expanding chain" (EG 223).

Francis articulates this more concretely with reference to the possibility of transforming conflicts. His device "unity prevails over conflict" (EG 226-230) does not mean that conflicts should be avoided. Neither does he want people to "remain trapped" in conflict. ${ }^{4}$ On the contrary, conflict must be taken seriously, it must "be faced," "resolved," and above all "transformed" into "a link in the chain of a new process" (EG 227). That means that it is necessary to go "beyond the surface of the conflict" and to see those who participate in it "in their deepest dignity" (EG 228). The recognition of the humanity of the other, even of the person who is perceived as an "enemy," is a conditio sine qua non for peace.

The purpose of the transformation of conflict is not uniformity, because that would be an imposition upon people without recognition of their diversity. The purpose is to achieve a "life-giving unity," which is a unity that does not destroy particularity and individuality, and which can also be described as "reconciled diversity" (EG 230). In order to clarify what this means, Pope Francis refers to the metaphor of the polyhedron, which is the image of a situation "in which all parts converge, while each of them preserves its distinctiveness" (EG 236).

The realization of this complex unity is, as Scannone explains, the result of a dialectics of the polar opposites, which moves conflict towards a "higher plane and preserves what is valid and useful on both sides" (EG 228). Francis's dialectics of the polar opposites is influenced by Guardini's "Der Gegensatz: Versuche zur einer Philosophie des Lebendig-Konkreten" and according to Scannone it is also comparable with Enrique Dussel's anadialectics and Aquinas' analogy (affirmation, negation, eminence). ${ }^{5}$

\section{A Spiritual Underpinning}

Pope Francis's belief in the very possibility of peace as a life-giving complex unity is grounded in a profound spiritual intuition, more precisely in a strong confidence in God's active presence and redemptive power: "In the heart of this world, the Lord of life, who loves us so much,

${ }^{4}$ Juan Carlos Scannone, "Violence socio-politique, communauté chrétienne et libération," Transversalités I47 (2018): 77.

5 Ibid., 78. 
is always present. He does not abandon us, he does not leave us alone, for he has united himself definitively to our earth, and his love constantly impels us to find new ways forward" (LS 245). God does not act as a sort of other-worldly deus ex machina, but, as Erik Borgman explains, via his presence in the world "working via a mysterious interconnection." He acts via an interconnection in which all the components "protect, nourish, complete, restore, make more dynamic, and open new possibilities," doing so "in their diversity and multicolored character." "The power of God is the capability to integrate. In Laudato Si' Pope Francis articulates this as follows: "Everything is related, and we human beings are united as brothers and sisters on a wonderful pilgrimage, woven together by the love God has for each of his creatures and which also unites us in fond affection with brother sun, sister moon, brother river and mother earth" (LS 92). Indeed, as the Catechism states "God operates in his creation via the interdependence of all creatures.... Creatures exist only in dependence on each other, to complete each other, in the service of each other." 7 It is through God's presence and action in the emergent reality, that a breakthrough of the good and thus of peace is possible, ${ }^{8}$ because God is as Basil the Great wrote, "goodness without measure" (LS 77).

In Laudato Si' this mystic-theological idea of God, who weaves together all that exists through his love, is not only the condition for the possibility of an effective peacebuilding, but it also constitutes an obligation to interpret reality in a holistic perspective and consequently the obligation to overcome fragmentation and disconnection: "the subdivision of knowledge risks to become irrelevant when it loses its sense of the whole, when it does not pay attention to the 'relationships between things', when it disregards the wider horizon" (LS IIo). For peacebuilding and peace research this means that "peace, justice and the preservation of creation" are to be interpreted as "three absolutely interrelated themes which cannot be separated and treated individually without once again falling into reductionism" (LS 92). This sort of integrated thinking is, according to Francis, not possible without inner peace: "inner peace is closely related to care for ecology and for the common good." It is "reflected in a balanced lifestyle together with a capacity for wonder which takes us to a deeper understanding of life." In

${ }^{6}$ Erik Borgman, "Deelnemen aan het goede: De contemplatieve politiek van de encycliek Laudato Si," Tijdschrift voor Theologie 56 (2016): 209 [Participating in the Good: The Contemplative Politics of the Encyclical Laudato Si'].

7 Catechism of the Catholic Church (Vatican City: Libreria Editrice Vaticana, 1994), par. 340. Quoted in LS 86.

8 Borgman, "Deelnemen aan het goede," 2 IO. 
other words: peace requires that one contemplates "the Creator who lives among us and surrounds us, whose presence must not be contrived but found, uncovered" (LS 225 / EG 7I).

\section{Peace, the Migrants and the Necessity of a Contemplative Gaze}

Francis's peace ethic is also underpinned by a spirituality of opening the human heart to the suffering of others. In Laudato Si' he invites his readers to integrate "the suffering of crucified people into our own suffering." It is from this profound spiritual attitude that a sense of solidarity and commitment to act emerges: "Our goal is not to amass information or to satisfy curiosity, but rather to become painfully aware to dare to turn what is happening to the world into our personal suffering and thus to discover what each of us can do about it" (LS I9). Without such a fundamental openness to the suffering of others and what happens in the world, our culture becomes dominated by a general "globalization of indifference" which is a real threat to peace, because of its "disinterest and lack of engagement, which only helps to prolong situations of injustice and grave social imbalance," and which causes conflicts, violence and insecurity. ${ }^{9}$ The alternative is, as he wrote in his message for the World Day of Peace 20I5, globalizing fraternity. Fraternity and solidarity are a foundation and pathway of peace and a prerequisite for fighting poverty. ${ }^{10}$

Pope Francis's emphasis on the negative consequences of indifference, is particularly strong in his commitment to migrants and refugees. In his homily at Lampedusa he explains that indifference is caused by our materialism and patterns of consumerism:

The culture of comfort, which makes us think of ourselves, makes us insensitive to the cries of other people, makes us live in soap bubbles which, however lovely, are insubstantial; they offer a fleeting and empty illusion which results in indifference to others; indeed, it even leads to the globalization of indifference. ${ }^{\text {II }}$

9 Message of His Holiness Pope Francis for the Celebration of the 49th World Day of Peace: "Overcome Indifference and Win Peace", http://w2.vatican.va/content/francesco/ en/messages/peace/documents [accessed November 27, 2018].

ro See also Francis's Message for World Peace Day 2014.

II Pope Francis, Homily, Arena sports camp, Salina Quarter, Lampedusa July 8, 2013, as quoted in Jorge E. Castillo Guerra, "A Church without Boundaries: A New Ecclesial Identity Emerging from a Mission of Welcome: Reflections on the Social Magisterium of Pope Francis as Related to Migration," Journal of Catholic Social Thought I4, no. I (2017): 5 I. 
The point is that this indifference not only dehumanizes migrants and refugees, but makes us all "anonymous persons," "unnamed," "leaders without names and without faces."

Pope Francis's Message for the Celebration of the sIst World Day of Peace (January I, 20I8) is explicitly devoted to the migrants as "men and women in search of peace." ${ }^{13}$ In this text he exhorts Christians to encounter migrants with a "contemplative gaze." This gaze enables them to see that all "belong to one family, migrants as well as the local populations that welcome them," that all have "the same right to enjoy the goods of the earth," and that all have the same universal destination. In Francis's perspective migrants are not a threat to peace, but a source of "enrichment for the life of the nations that receive them." In the same peace message he proposes four actions for the creation of a culture of encounter (cultura de encuentro $)^{14}$ with migrants and refugees: welcoming, protecting, promoting them, for example by "ensuring access to all levels of education for children and young people," and integrating them with the guarantee of full participation in the life of the society that welcomes them. He even proposes two "Global Compacts" for regular migration, and for refugees.

\section{Dialogue with Enemies}

Another aspect of Francis's peace theology is a detail with huge consequences: if peace is a process in which new possibilities emerge, we must enter into dialogue with all who can contribute to it: not only other Christians, or members of other religions, or scientists (EG 238-258), but also "people who can be considered dubious on account of their errors" (EG 236). With these words Francis implicitly reconfirms the distinctions made by Pope John XXIII, in Pacem in Terris, more precisely the distinction between persons "who retain in every case" their "dignity as a person," and "the [condemnable] philosophies to which they sometimes adhere," Is as well as the distinction between "false philosophical teachings" and

${ }^{12}$ For another interpretation of Francis's address in Lampedusa see: Anna Rowlands, "After Lesvos and Lampedusa: The European 'Crisis' and Its Challenge to Catholic Social Thought," Journal of Catholic Social Thought I4, no. I (2017): 63-85.

${ }_{13}$ Message of His Holiness Pope Francis for the Celebration of the SIst World Day of Peace, January I, 20I8, http://w2.vatican.va/content/francesco/en/messages/peace/documents [accessed November 27, 2018].

${ }^{\text {I4 }}$ Juan Carlos Scannone, "Pope Francis and the Theology of the People," Theological Studies 77, no. I (2016): II8-I35.

is John XXIII, Pacem in Terris, 158. 
"movements which can play a role in the peace process, even if these movements owe their origin and inspiration to these false tenets." These important distinctions allowed Pope John to welcome people whom many of his contemporaries considered enemies of the Church, such as the family members of Nikita Khrushchev, leader of the Soviet Union, who were warmly received in the Vatican. That friendly encounter created one of the conditions for the solution of the Cuba crisis. ${ }^{16}$ In the same way Pope Francis invites peace builders to include in the process all those who can be of use and whose thinking and acting "contains elements that are positive and deserving of approval." ${ }^{\prime \prime}$ Both for Pope John and Pope Francis, a hand extended to so-called enemies is more fruitful than a condemnation. To say it with his own words: it is more important to concentrate on what we have in common than on what divides us. Have the courage to say: it is "easier to build bridges than to build walls." ${ }^{\text {"18 }}$

\section{Other Components of Francis's Peace Vision: Non-violence, Accompanying the Poor on Their Way to Liberation and Building Bridges}

A clear example of his unambiguous option for nonviolence can be found in his Message for the Celebration of the Fiftieth World Day of Peace (January I, 20I7), in which he states that "to be true followers of Jesus today (...) includes embracing his teaching about non-violence." Like Thomas Merton and Pope Benedict XVI he emphasizes that nonviolence is

not merely tactical behaviour but rooted in a person's way of being, the attitude of one who is so convinced of God's love and power that he or she is not afraid to tackle evil with the weapons of love and truth. Love of one's enemy constitutes the nucleus of the Christian revolution. ${ }^{19}$

${ }^{16}$ For an analysis of the peace ethic in Pacem in Terris see Johan Verstraeten, "Pacem in Terris as Turning Point: How the Catholic Church Has Attempted to Overcome War by Its Ethics and Practice of Peace," in Peace through Law: Reflections on Pacem in Terris from Philosophy, Law, Theology, ed. Heinz-Gerhard Justenhoven and Mary Ellen O'Connell, Studies on Peace Ethics (London: Bloomsbury and Baden-Baden: Nomos, 20I6), II-29.

${ }_{17}$ Pacem in Terris, 159.

I8 Message of the Holy Father Francis for the Opening of the Annual Meeting for Peace, "Bridges for Peace" (Bologna, I4-I6 October 20I8), http://press.vatican.va/content/salastampa/en/bolletino/pubblico/20I8/Io/I4/I8IOI4d.html [accessed January 2I, 20I9].

19 Message of His Holiness Pope Francis for the Celebration of the soth World Day of Peace, January I, 2017, http://w2.vatican.va/content/francesco/en/messages/peace/documents [accessed November 27, 2018]. 
According to Francis, peace also implies integral human development in the perspective of the preferential option for the poor. This is not only a matter of "caring or thinking for the poor," but acknowledging the poor's active participation in decisions that concern their lives (EG 49). They are neither objects of decisions taken by experts, nor "passive objects for the more powerful donor's greater spiritual good." ${ }^{20}$ They are subjects of their own destiny and actors from whom we have much to learn. In his address to the popular movements at Santa Cruz (Bolivia, July 9, 20I5) Francis's standpoint is unambiguous:

You the most humble, the exploited, the poor and excluded... the future of the world is to a large extent into your hands, in your capacity to organise yourself, and to promote creative alternatives. Don't underestimate yourself, you are the sowers of change. ${ }^{2 \mathrm{r}}$

Francis is convinced that change comes from the periphery.

Accompanying the poor on their path toward liberation requires not only a direct encounter with poor people, but also structural analysis (EG 188). An important result of such an analysis is the recognition that "inequality is the source of social ills" (EG 203) and hence an obstacle to peace.

Interesting is also Francis's proposal for the year 2018 to build "Bridges of Peace." In particular, religions are invited "to create connections that lead to real encounters, bonds that unite," and "paths that help to overcome conflicts and harshness." Bridges of peace are "memories of communion" that heal the wounds of history and lead to the construction of "the fabric of peaceful coexistence in the future." 22

\section{War and Deterrence}

Against the backdrop of Francis's interpretation of peace "which is much more than the absence of war" (LS 225), we can understand his critical attitude vis-à-vis war and deterrence, which he rejects as an unsuitable means for solving conflict or stopping unjust aggression.

${ }^{20}$ Susan R. Holman, Beholden: Religion, Global Health and Human Rights (Oxford: Oxford University Press, 2015), 6.

${ }_{21}^{21}$ Translated from Le Monde, Friday, July io, 2015.

${ }_{22}$ Message of the Holy Father Francis for the Opening of the Annual Meeting for Peace, "Bridges for Peace" (cf. n. I8). 
Francis's most striking idea in this regard is that the Third World War is not simply a future threat. It is already ravaging the world. In his 2017 World Day of Peace message he interprets the many wars in the world as "a horrifying world war fought piecemeal." This war includes not only armed conflicts but also terrorism, organized crime, unprecedented acts of violence, abuses suffered by migrants and victims of human trafficking, and the devastation of the environment. In this horrifying world war, violence "is not the cure of our broken world." It leads to "the death of many people if not all." ${ }^{23}$

This broad definition of the Third World War does not make Francis blind to specific issues, such as disarmament. One of his major concerns is nuclear deterrence and proliferation, a ticking bomb he condemns in more radical terms than his predecessors. Mathias Nebel and Gregory M. Reichberg have articulated the evolution of Papal thinking on nuclear deterrence in a Caritas in Veritate Foundation working paper on Nuclear Deterrence: An Ethical Perspective. ${ }^{24}$

This working paper describes how the magisterium of the Catholic Church has gradually changed its judgment on nuclear deterrence from "a practical but non-permanent fixture that would allow time for the responsible parties to engage in disarmament," and from a recognition that this sort of peace remains a dangerous and fragile path, to a clear statement that deterrence no longer functions as an instrument that allows for disarmament. ${ }^{25}$ The consequence is that both threatening with nuclear weapons and the possession of these weapons can no longer be acceptable. Symptomatic of the new policy of the Vatican during the pontificate of Pope Francis is the title of a document issued by the Holy See on the occasion of the Vienna Conference on the Humanitarian Impact of Nuclear Weapons (20I4): "Nuclear Weapons: Time for Abolition." In this text the Holy See clearly states that "the very possession of nuclear weapons, even for purposes of deterrence, is morally problematic." According to Nebel and Reichberg, this judgment is summed up later in even stronger terms: "Now is the time to affirm not only the immorality of the use of nuclear weapons, but the immorality of their possession, thereby clearing the road to nuclear abolition." ${ }^{26}$ In Pope Francis's personal message to the Vienna

${ }^{23}$ Kenneth R. Overberg, "Papal Wisdom for the Long Term," The Way 57, no. 4 (20I8): II2.

${ }^{24}$ Mathias Nebel and Gregory M. Reichberg, Nuclear Deterrence: An Ethical Perspective (Chambésy: Caritas in Veritate Foundation, 2015).

${ }^{25}$ Ibid., 6.

${ }^{26}$ Ibid., Io. 
conference, one of the arguments against nuclear weapons is that they cause unnecessary suffering. The condemnation that is valid for other sorts of weapons, such as chemical or bacteriological weapons, which are condemned by international law, is now also valid for nuclear weapons. In short, according to Francis, nuclear deterrence "cannot be the basis for an ethics of fraternity and peaceful coexistence among peoples and states." ${ }^{27}$ It is important to note in this context that this did not remain a matter of words. During Francis's pontificate the Holy See was the first to ratify the Nuclear Ban Treaty, to which the Vatican diplomats substantially contributed. During a conference on the occasion of the nuclear weapons ban treaty (Vatican City, November IO-II, 20I7), Francis declared unambiguously that "If we also take into account the risk of an accidental detonation as a result of error of any kind, the threat of their use, as well as their very possession, is to be firmly condemned. ${ }^{28}$ Francis is convinced that the possession of and deterrence with nuclear weapons create a "false sense of security," and that "doomsday predictions can no longer be met with irony or disdain" (LS I6I).

\section{Conclusion}

Pope Francis's concept of peace is neither utopian nor unrealistic, but an expression of a deep and complex realism, based on a mystic understanding of reality as process in which God is present and creates new possibilities. This mystic realism allows him a forward-looking imagination which John Paul Lederach translates in secular terms as the capacity to "imagine responses and initiatives that, while rooted in the challenges of the real world, are by their nature capable of rising above destructive patterns and giving birth to that which does not yet exist." ${ }^{29}$ In the context of Pope Francis's peace praxeology this implies fully entering into the fabric of society (including its conflicts), transforming conflicts, creating new processes, responding to suffering, welcoming migrants, destroying mental walls, abolishing nuclear weapons, and above all, building bridges towards all who can contribute to a greater good. As bridge builder, Francis is a pontifex maximus in the fullest sense of the word.

27 Pope Francis, Message to the Vienna Conference on the Humanitarian Impact of Nuclear Weapons, December 7, 2014, ibid., 83-84.

${ }^{28}$ Quoted from the text distributed during the conference.

29 John Paul Lederach, The Moral Imagination: The Art and Soul of Building Peace (Oxford: Oxford University Press, 2005), I82. 